\title{
FOOTBALL AS A NEW FORM OF POLITICAL COMMUNICATION FOR ST. PAULI FOOTBALL CLUB SUPPORTERS
}

\author{
Kiki Esa Perdana
}

\begin{abstract}
The development of political communication has changed the conventional concept of politics and football. A broader understanding of political system and democracy has led football into something new, football is a new form of media and supporter is conveying a message. This article assesses how supporters use football as a medium for political purpose and how the involvement for supporters in the process. The results indicated that in the end, political communication is a process and affected by a political culture in society.
\end{abstract}

Keywords: political communication; football supporters; international media; mass communication

Introduction

Political communication, defined as all communications involving political messages and political actors, relating to power, government, and policies, is one of the most powerful channels in shaping public opinion through mass media. This means that public opinion, i.e. the aggregate of individual attitudes or beliefs held by the adult population, is by and large the result of political communication itself.

Modern human life in this world can be divided into many categories of interest and activity, and sports is surely one of the fields that is increasingly important. Within this category, football 


\section{Dinamika Global | Volume 01 | No.2 | Desember 2016}

may be considered as the world's most popular sport, attracting the attention of people on global scale with big events, such as world cup and national competitions broadcast transnationaly, and also being one of the most important activities humans choose for physical exercise.

In general terms the history of modern football starts in 1863 with the establishment of the English Football Association (FA). This agency together with subsequent organizations such as the World Football Federation FIFA. Issued the basic standard rules for the football game, and regulated referee assignments, as well as the transfer of the players. In 1908 football became part of the Olympics games while FIFA also started the football championship between nations in what is popularly known as the World Cup.

The history of football in Germany itself officially began in January 28, 1900, when Deutsche Fussball-Bund (German Football Union) formed in Leipzig. The foundation for football's rapid rise to vast popularity amongst the German people and the DFB's progress towards becoming a sporting authority of high importance on a socio-political level was laid. Milestones in these developments were the introduction of the German championship in 1903, the formation of the national team, who began playing their games in 1908 and the outlining of national and regional associations, as well as the implementation of the DFB general assemblies. Today, about 25,000 clubs organized in DFB with nearly 170,000 teams and over two million active players, DFB become the largest membership sports federation in the world. 


\section{Dinamika Global | Volume 01 | No.2 | Desember 2016}

St. Pauli is a district located in the Hamburg-Mitte, on the right bank of the Elbe river, the Landungsbrücken are a northern part of the port of Hamburg. The big port of Hamburg in St. Pauli led many sailors to Hamburg who preferred to spend their spare St. Pauli. Since then has been many bars, cheaper living cost and it is still best known as Hamburg's red-light district area, named Reeperbahn.

St. Pauli football club began their first match in 1907 and officially established in may 1910. The team on their early years, played in lower level competition in Germany. The club formed as it represents the sailors, lower working class and political activist who live and work in St Pauli district. In the mid 1980s, the transition in St. Pauli began, from ordinary and traditional football club, St. Pauli changing into modern club. Further, the supporters of St. Pauli football club adopted crossed skull and bone as their unofficial icon, which symbolized the poor against rich clubs, they also show their commitment about social activism and anti-fascism political activity. St. Pauli football club is the first football club in Germany who officially forbid right-wings political activity on their stadium.

St. Pauli well known as world's most left-wing football club. On 2014, St. Pauli supporters invited many street artist from many countries to help them with the "Millerntor Gallery", a program itself is a creative platform, inviting people to take part in a discourse concerning sustainable responsibility. The focus lies on the work of global artists, which generates stimuli for the visitors through an aesthetic experience. This discourse can be experienced 
through the universal languages of art, music and football, and the communal activities act in a meaningful and activating manner. This unconventional gallery incorporates scientific and political components, and uses public panels and expert discussions in order to scientifically question the concept's meaningful scope, and to make the discourse accessible to a broad public. All of the event's profits benefit Viva con Agua's projects, which have the objective to relieve the global problem of insufficient water and sanitary supplies (http://millerntorgallery.org/, accessed December 9 2016). During PAGIDA movement in 2015 that attracted wide range of football supporters in Germany, especially football hooligans from Cologne and Dresden. St. Pauli FC given its club friendly match against Borussia Dortmund with match-motto "Refugees Welcome". Around 1,000 migrants, mostly from Middle East and Africa, in various accommodations around Hamburg are invited. St. Pauli is also inviting their supporters and residents living near the stadium to meet the migrants and get to know them.

Football in general, and more particularly in St. Pauli FC, have been institutions used as a medium for political purposes: clubs are associations with the political activist to attract others who may be persuaded to support the political interests attached to the club. Attributes and symbols associated St. Pauli FC are used by political activist and become prevalent during their social campaign periods. Because of a variety of advantages and as logical consequences of the entanglement between football and politics, St. Pauli has become very attractive as political media used by political activist to delivered their messages. 


\section{Dinamika Global | Volume 01 | No.2 | Desember 2016}

Literature review

Communication studies (Hovland 1953, Mulyana 2005) is a social science which deals systematically with every side of human communications, in which individual (the communicator), transmit stimuli (usually verbal symbols) to modify the behavior of other individual. Of course, any human statement, as a core object of this scene, has many different aspects to analyze, such as what media did they use, what feedback they receive and try to trigger, the techniques and methods of the statements, system, etc. This definition is simple, but serves to explain the relation to other fields of study, including politics (Anwar 1988).

Brian Mcnair define political communication as "purposeful communication about politics", that mean that its not only covers verbal or written statement, but also representations such as dress or logo design (Mcnair 2003). With other words, it includes all aspects that may develop a "political identity" or "image". Pipa Norris stated that "The process operates down-wards from governing institutions towards citizens, horizontally in linkages among political actors, and also upwards from public opinion towards authorities" (Norris 2004). Political communication process movesin horizontal and vertical planes and anyone may become a political actor of their own accord.

Football's capability to mobilize the masses has been wellestablished, by the fact it has become the world's most popular sport in the world. Furthermore, as Alexander Cárdenas puts it "Football represents a professional activity, an instrument to 


\section{Dinamika Global | Volume 01 | No.2 | Desember 2016}

mobilize the masses, a profitable business, also a focus of violence and unrest, and most recently, it has emerged as a tool for social development and peace" (Cardenas 2014). Media cover, sponsors and access to large groups of supporters, provide distinct advantage to the majority of the political elites.

Government, as one of political communication actors, is most active not only in normal political communication channels, but also in football. In United Kingdom in 1997 in order to cope with social problem, the role of government was needed, and a special football task force was established (Brown 2002). This football task force job was assigned to eliminate racism in football, improve disabled access in stadium to ticket pricing policies, which had become a big problem in the UK during the early stage of the English Premiere league. The UK football task force was also recommended to other European countries by the UK Goverment, to maximize their own social and economic benefits of sports.

Supporters also play a big part on political communications. In an example about Livorno supporters in the Italian Football competition, Mark Doidge explains how "through match day choreographies, supporters present their political affiliation" (2013). Other than having a strong working class background when ruled by the Medici family for four centuries, Livorno's place in history was also written in 1921 when the Italian Communist Party was establishedthere. With their strong historical background in politics, it is not uncommon for Livorno supporters to stage a variety of political protests to raise awareness on specific issues in the stadium. The same things are also conducted by ultras group in 
Spain, as stated by Spaaij and Viñas "although various radical political ideologies has existed within the ultras scene from the start, they had now been transformed into a major influence for group identification" (Spaaij \& Vinas 2005). This studies make it clear how football can be a media in delivering a political message and also as an example of how supporters connect politics with football and become political actors. My research will broach similiar issues among supporters group of St. Pauli.

Harrop explain about political marketing, cited by Kolovos and Harris, that "political marketing as being not just about political advertising, party political broadcasts and electoral speeches but covering the whole area of party positioning in the electoral market" (Harrop 1990, Kosovos \& Harris 2005). Political elites who have aparticular involvement in a football could be interpreted as having a strategic political position. A wide variety of political messages can be conveyed more effectively, due to direct contact andability to understand their constituents in the realm of football.

Political message can be achieved in various ways, one of them is to make use of them any potentials football provides. This essay is envisioned to bring a new perception on political communication, especially in football, how football has become a tools of political expression and propaganda to shape the public opinion. 


\section{Dinamika Global | Volume 01 | No.2 | Desember 2016}

Discussion

Political message in the process of political communication in modern era signed with broader understanding of political system and broader understanding of democracy. Political messages are implemented on various (verbal and non-verbal) dynamic situation and condition, use alternative media and alternative places.

The actor in political communication, not only the elected officials or government employees on any level involved in an issue, but also any person, group, or private organization that has a large influence on a political situation or issue. It means, political actors are political participation that based on rights of freedom to speak out, assemble and associate; the ability to take part in the conduct of public affairs; and the opportunity to register as a candidate, to campaign, to be elected and to hold office at all levels of government (http://www.un.org accessed December 10 2016). On this point of view, supporters is a political actor, their identities are often constructed on divides such as locality, social-class, religion or political view. Many football clubs well known for its supporters, some of them not only for their songs and performances, but for their political views. The actions of supporters are occasionally extreme and some of them may influenced by political ideologies, ranging from those who recognized from nationalists to anti-fascist. In recent decades, the culture of supporters has become a vocal point for the movement against the commercialization of sports and football in particular. 
The media used by the actors also changing, from traditional media, modern media and now are being followed by new media, where media texts and images are more easily accessible than ever through digital databases. The mass communication no longer only related to newspaper, magazine, and book publishing, radio, television, film, or even via internet as mediums disseminating information, news and advertising, but also through music, art, and even football. Football as the most popular sports has a lot advantages, the more attendees or viewers with full coverage and live broadcast, the broader message delivered. Football now considered as an effective intermediary on conveying an information from sender to audience efficiently.

The comprehension of football is media with supporters sending out various political message is clearly possible. Football and politics have always proved a tangible mix. Tuñón and Brey stated that sports interacts with both social (cultural) and political dimensions within the ongoing globalization process. Football, nowadays the most popular sport world wide, makes those interactions even more visible and evident (Tunon \&Brey 2012). Football has become a strong identity builder in many countries. Various issues brought up, from social movement into radical political ideologies, football obviously have often been used with evident and varying political aims.

On 1980s, Hamburg and German football are penetrated by fascist hooligans who support neo-nazi, St. Pauli at that time are port district inhabited many sailors come from all over the world. A place who accustomed with diversity, St. Pauli suddenly becoming 


\section{Dinamika Global | Volume 01 | No.2 | Desember 2016}

an escapement for those who disagree with fascism and neo-nazi. Nowadays in St. Pauli FC, supporters are highly organized and critical, they promote movement with a distinct anti-racist, antihomophobic and anti-sexist stance, committed to political action and social education inside and outside Germany. And also during the 1980s, local squatters, anarchists, sex workers, students and punks started filling the creaking terraces of the Millerntor Stadium, giving it a very different character. While the rest of German football was mired in Nazism, St Pauli took a more progressive path.

Some of their organized activities are; Anti-fascist research and discussions (2006), visit to Yad Vashem memorial site in Israel (2008), discussion of the influence of right extremism on the Polish fan scene (2009), congress in Lüneburg "Active against Nazis" (2010), memorial day "Remember for the Future" to commemorate the liberation of Auschwitz (2010), a yearly Anti-racist tournaments among supporters worldwide, project KiezKick which engages in socially educative, ethnically and gender inclusive free training and fun activities, humanitarian aid for forced laborers in Belarus (2007) and viva con Agua, a project promoting access to clean drinking water in developing counties. With strong political background supporters group in St. Pauli FC preserve their identities that maturely formed, the identities as leftist that represent low working class. Those characters what made them different from others.

St. Pauli football club has been affected by all sorts of changes manifested in its immediate environment, has actively 


\section{Dinamika Global | Volume 01 | No.2 | Desember 2016}

demonstrated its interest in matters that not only in football, but also go beyond the realm of football (https://www.fcstpauli.com accessed 8 december 2016). Driven by an identity that commands social reform, the supporters of St. Pauli FC have certainly played impressive role in reshaping fandom in German football. St. Pauli FC made available the necessary socio-political conditions for expressing political message through football culture. Playing football under the banners of leftism, the club succeeded in developing an appealing identity that was not only famous in Germany or Europe, but also around the world.

\section{Conclusion}

Political communication activity in the end is a process, parts and also affected by a political culture in society. But at the same time, political communication is also established, maintain and bequeath political culture, concerning their massage structure and patterns.

This political communication process happens in every level in society and on every possible places for information exchanges not only by government or political elites, but also between individuals or groups. Political communication in St Pauli can not be separated from their local identities that holds strong culture on politics and social movement. Political communication in St Pauli are still represent and characterized as low working class politics. 
In the end the message on modern political communication could delivered into various medium, including football. St Pauli FC has the capacity becoming media that conveying political aspiration from those who grows with strong political identity that they maintained from past to the world.

Bibliography

Arifin, Anwar, 1988, Ilmu Komunikasi: Sebuah Pangantar Ringkas, Jakarta, Rajawali.

Brown Adam, 2000, European football and the European union: Governance, participation and social cohesion - towards a policy research agenda,Soccer \& Society, 1:2, 129-150,

C. Hoepfl, Marie. 1977. Choosing Qualitative Research: A Primer for Technology Education Researchers. Jurnal of technology Education. Volume 9, Number 1. Virginia Tech.

Cárdenas Alexander, 2014, The Global Journey of Football: From the origins of the beautiful game to its recent use as a social catalyst, Hamburg, Anchor Academic Publishing 2014.

Creswell, J. W., V. L. Plano Clark, M. Gutmann, and W. Hanson 2003 Advanced Mixed Methods Research Designs. In Handbook of Mixed Methods in Social and Behavioral Research. A. Tashakkori and C. Teddlie, eds. Pp. 619-637. Thousand Oaks, CA: Sage. 
Doidge Mark, 2013, The birthplace of Italian communism': political identity and action amongst Livorno fans, Soccer \& Society, $14: 2,246-261$.

Driscoll, David L.; Appiah-Yeboah, Afua; Salib, Philip; and Rupert, Douglas J., "Merging Qualitative and Quantitative Data in Mixed Methods Research: How To and Why Not" (2007). Ecological and Environmental Anthropology (University of Georgia). Paper 18.

Spaaij Ramón, Viñas Carles, 2005, Passion, politics and violence: A socio- historical analysis of Spanish ultras, Soccer \& Society, $6: 1,79-96$

Kolovos, Ioannis, harris Phil. 2005. Political marketing and political communication: the relationship revisited. Otago University research archive. University of Otago.

L. Berg, Bruce. 2001.Qualitative research methods for the social sciences / Bruce L. Berg. -- 4 th ed. Boston. Allyn and Bacon.

Mcnair, Brian. 2011.Political Communication Bundle: An Introduction to Political Communication (Communication and Society). Routledge; 5 edition. New york. Routledge, Francis \& Taylor Group.

Mulyana, Deddy, 2005, Ilmu Komunikasi: Suatu Pengantar, Bandung, Remaja Rosdakarya. 
Norris, Pippa. "Political Communication: Technological Diffusion and Democracy." International Encyclopedia of the Social and Behavioral Sciences. .Pergamon/Elsevier Science, 2001

W. Creswell, John. 2007. Qualitative inquiry and research design, choosing among five approches. California. Sage Publications.

Digital source:

http://edition.cnn.com/2010/SPORT/football/08/18/football.st.pa uli.punks /

https:/ /www.fcstpauli.com/en/club/history/

http://www.reeperbahn.org.uk/hamburg.asp?show=history

http://www.shortlist.com/entertainment/when-punk-and-footballcollide

https: / /www.theguardian.com/football/blog/2015/sep/06/stpauli-club-that-stands-for-all-the-right-things-except-winning 